\title{
Bringing Map Learning to 'Life' by Using the Environment as a Learning Resource
}

\author{
Sarita Ramsaroop
}

\section{Abstract}

The last two decades have brought to light local and international research on problems encountered by learners when learning Geography at school, especially map work. One of the reasons provided for poor learner performance relates to teacher expertise in teaching this subject. This research explored how first-year student teachers from a university in Johannesburg, South Africa, merged their coursework with their fieldwork when learning map work; and how they were able to re-imagine their teaching of map skills to learners in the Intermediate Phase of the primary school. In addressing the research aim, a qualitative case study method of inquiry, using open-ended questionnaires, was undertaken. Drawing on the findings from the data, I assert that using Kolb's experiential learning theory, to integrate student teacher learning in coursework and fieldwork, not only strengthened pedagogic content knowledge, but also enabled student teachers to exhibit agency. The data confirmed that student teachers configured their understandings of map work by engaging their past experiences with the present (learning in coursework and fieldwork) to re-orientate their learning towards the future (how they will teach learners). For example, student teachers were empowered to take agentic action by reflecting on their learning in coursework and fieldwork to make informed pedagogical choices on how they would teach this content area to learners in the primary school. Thus, the foundations for learning to teach geographical enquiry skills were being developed.

Keywords: fieldwork, student teacher learning, map work, student teacher agency, experiential learning 


\section{Background to the Study}

The Social Sciences curriculum aims to provide opportunities for learners to make connections to their everyday realities and to develop skills that foster critical thinking to question these everyday realities (DBE 2011). The subject Social Sciences includes the fields of History and Geography. The content area 'geographical skills and techniques' is included in the Curriculum and Assessment Policy Statement (CAPS) in South Africa from Grades 4 - 9 in the field of Geography; and continues into Grades 10 - 12 in the subject Geography (DBE 2011). The geographical skills and techniques that need to be developed are classified into the following categories: map-work skills (such as reading, interpreting and synthesising information from maps); map-work techniques (such as calculating distances and gradients); and geographical enquiry skills (such as following the scientific methods of enquiry) (Umalusi and Higher Education South Africa, 2010). The CAPS curriculum stipulates that learners need to develop mapping skills (DBE 2011:13). In developing the mapping skills of learners in the primary school, the Intermediate Phase Social Sciences Geography curriculum expects learners to understand concepts such as grid referencing; compass direction; reading and drawing maps; and scale (DBE 2011). By introducing learners to these basic map work skills in the Intermediate Phase, the foundations for learning geographical enquiry skills are laid down. Innes (2003:727) asserts that if learners are to become skilled in the use of maps, there needs to be clear progression from basic map reading, to map analysis, to map interpretation.

From the above discussion, it is evident that teacher education programmes need to equip student teachers with the necessary knowledge on 'what' and 'how' to teach map skills to learners in the Intermediate Phase. According to the Department of Higher Education and Training (DHET) policy on MRTEQ (2015:25), all Intermediate Phase student teachers must be equipped with 'sufficient broad background knowledge to understand the requirements of all subjects in the Intermediate Phase curriculum'. The implication is that all student teachers specialising in Intermediate Phase teaching should have sufficient knowledge to teach all subjects, which includes Social Sciences and Geography. However, research over the last two decades has highlighted the problems encountered by learners at school when learning Geography, including map use (Innes 2003; Larangeira \& van der Merwe 2016). These difficulties continue into the first-year of university, with many 
Geography students still experiencing difficulty with map interpretation (Larangeira \& van der Merwe 2016).

Research in South Africa on how student teachers draw on their experiential learning when learning to teach map work skills in the primary schools is limited. This study, therefore, explores how first-year student teachers merge their learning of map work skills during coursework with their learning during fieldwork to re-imagine how they would teach map skills to learners in the Intermediate Phase of the primary school.

\section{Teaching Map Work in the Primary School}

Geography involves the study of people and the earth taking into consideration place, space and environment (Weeden 1997). Investigating spatial patterns and developing locational knowledge is central to the discipline, with maps being a vital tool in explaining such patterns and processes (Brunn \& Dodge 2017; Weeden 1997). Maps are therefore essential materials for understanding, analysing and solving problems in Geography pertaining to place, space, and human interaction with the environment (Koc \& Demir 2014; Larangeira \& van der Merwe 2016; Maxim 1997; Natoli 1988). Therefore, to teach Geography without a map would be very difficult. In South Africa, maps are regarded as the basic tools of Geography for the primary school learner (Beets \& Le Grange 2005). I would also add that maps lay the foundation for learners to engage with ICT when learning, for example, Geographical Information Systems (GIS), a compulsory component of Geography CAPS (DoE 2011) in Grades 10 - 12.

Although map-related education takes place mainly within the discipline of Geography, its importance extends beyond the Geography classroom (Koc \& Demir 2014; Liben, Kastens \& Stevenson 2002). For example, it plays an important role in developing representational and spatial skills in children, as it develops and strengthens their general symbolic and spatial reasoning (Liben, et al. 2002). It teaches learners how to navigate by learning how to interpret symbols and how to understand scale. It facilitates an understanding of the 'very nature of representation', which Liben et al. (2002:270) explain as an 'understanding that does not come automatically to children'. These scholars further elaborate by explaining that both younger and older children find it confusing to understand that the symbols in maps 
represent other objects (Liben et al. 2002). Lessons from map learning can be applied to a diverse range of fields such as ecology, geology, civil engineering and urban planning (Liben et al. 2002). Drawing from the aforementioned discussion, I would argue that it is imperative that all learners acquire basic map skills.

Unfortunately, learners, both locally and internationally, appear to experience much difficulty in understanding and applying map work concepts (Innes 2002; Larangeira \& van der Merwe 2016; Ying 1997; Yoshida 2015). In particular, South African learners have been found to have low levels of map literacy (Innes 2002; 2012). Some of the reasons for the poor performance of learners in map work appear to relate to teachers' pedagogy when teaching map work (Innes 2012; Lloyd \& Bunch 2010), specifically their overuse of theory (Ndlwana 1991; Ying 1997). In South Africa, learners reported that the concepts were taught in an abstract manner as they were not taught in ways that enabled them to compare maps to reality using photographs and practical field work (Larangeira \& van der Merwe 2016). Teaching map work by making concrete links to reality is necessary as it forms the basis for cartographic communication (Ying 1997). Another reason for the low levels of map literacy could be low levels of teacher expertise in teaching the subject. When Geography and History are integrated in the Social Sciences curriculum, teacher expertise can be questioned since the same teacher is expected to teach both fields of knowledge. Research in Australia has pointed to the compromised quality of Geography teaching stemming from a shortage of suitably qualified Geography teachers when Geography is integrated into the Social Sciences curriculum (Reitano \& Harte 2016). Teachers in schools assigned to teach Geography are generalists, with limited Geography knowledge, thus compromising the quality of Geography teaching and learning (Reitano \& Harte 2016).

As mentioned, teacher expertise is an area of concern in South Africa too. A report published by the Department of Education (DoE 2007) indicates that many teachers in South Africa still lack the epistemological and pedagogical skills to teach their area of specialisation effectively. Specific to teaching Geography, many teachers in the high school appear to lack the subject or pedagogical knowledge to teach geographical concepts and processes (Beets \& Le Grange 2005). In addition, most South African Geography teachers were trained in an era when summative assessment and rote learning were the dominant practices (Beets \& Le Grange 2005). This 
raises questions pertaining to the pedagogy used to teach Geography in a $21^{\text {st }}$ century classroom.

\section{Experiential Learning Theory as Pedagogy in Teaching Map Work}

It has been asserted that 'geographical inquiry begins with observations of physical features' (Maxim 1997:207). Through direct experience, learners are able to develop mental structures to connect theory and construct meaning. Fieldwork is, therefore, an important interface between teaching and learning as it links the theory to the 'real world' (Day 2012). In defining fieldwork, I refer to the definition as outlined by Scott, Fuller and Gaskin (2006 cited by Day 2012:313), that fieldwork is a 'formal process of study of the environment that takes place outside the classroom and that uses the environment as a learning resource'.

In this study, I make use of Kolb's experiential learning theory (1984) to understand how to merge student experiences with academic content to make learning real and relevant, as I view the interaction of knowledge, skills and experience as key to learning. Kolb (1984:38) asserts that 'learning is the process whereby knowledge is created through the transformation of experience'. I believe that it is through personal experiences that theory takes on meaning and fosters growth and critical thinking (Dewey 1933). At the core of Kolb's four-stage model, immediate concrete experience forms the basis of observation and reflection (Kolb 1984). Kolb refers to these four stages as concrete experience abilities (CE), reflective observation abilities (RO), abstract conceptualisation abilities (AC), and active experimentation (AE). These different stages incorporate different learning styles, giving credence to the notion that individuals have preferred learning styles (Kolb 1984). Healey and Jenkins (2000) assert that the theory offers a way of designing an entire module, or parts of it, using a learning cycle. In this particular article, Kolb's experiential learning theory was used to structure students' learning of map work skills.

\section{Designing the First-year Geography Module Incorporating Experiential Learning Theory}

In addressing the requirements of the DHET (2015), the module 'Introduction to Social Sciences for the Intermediate Phase' is a compulsory module for all 


\section{Sarita Ramsaroop}

first-year student teachers at a university in Johannesburg. The module aims to introduce students to the fields of History and Geography. The first-year group in this study consisted of students who had studied History or Geography or both up to Grade 12 level. It is also consisted of students who had never studied History or Geography beyond Grade 9. These first-year Intermediate Phase student teachers were taken for a weekend to Achterbergh, an outdoor camp located in Gauteng. The camp took place at the beginning of the year. The aim of the camp was to introduce student teachers to teaching as a profession. An eco-tourism field trip was included in the weekend. This field trip was designed to introduce student teachers to the fields of History and Geography in the Social Sciences. There is an abundance of research pertaining to the advantages of field trips for experiential learning (Dillon, Rickinson, Teamey, Morris, Choi, Sanders \& Benefield 2006; Fuller 2006; Greene, Kisida \& Bowen 2014; Noel \& Colopy 2006). In designing the activity pertaining to student teachers' learning of map work, I grounded their learning in direct observation and concrete experiences. At the camp, activities were designed such that student teachers learnt through direct observation and through group interactions, within the environment. In this camp activity, student teachers, working in groups of 10 - 15, made their way to different locations to study both humanmade and natural features that were present at the campsite. I asked students to take as many photographs as possible, using their cellphones, as these photographs would be used for a map work task during their coursework.

In the coursework component, they engaged with interpreting, analysing and drawing maps using different pedagogies such as group work, working with a peer, and whole-class discussions. They were then asked to refer to the Achterbergh camp and write a paragraph describing the route they followed from the conference venue (a site at Achterbergh) to the first, second, third and fourth location at the camp. In the paragraph, they were to include the direction they travelled and the features they experienced along the way, supported by the photographs they had taken of the area. Thereafter, they were to draw a map of the route that corresponded to their paragraph and pictures. Instructions provided for the drawing of the map were that it should include a title; the direction of true north; symbols (their own symbols were designed to show the features in the area); and a key to explain the symbols. Thus, I aimed to integrate the four stages of Kolb's experiential theory, namely, concrete experience abilities (CE), reflective observation abilities (RO), abstract concepttualisation abilities (AC), and active experimentation (AE) to 
strengthen student teacher learning of map work. Thereafter, I asked students to reflect on how they would teach map work to learners in the Intermediate Phase of the primary school. In so doing, the next cycle in Kolb's experiential theory commenced by using their concrete experiences (CE) to reflect (RO) and conceptualise (AC).

\section{Research Methodology}

Qualitative research, as described by Merriam and Tisdell (2016), is research conducted to understand how people construct meaning from their experiences. Within a qualitative research paradigm, different terms such as theoretical traditions, approaches, strategies or designs are used to denote the diversity of forms of qualitative research (Merriam \& Tisdell 2016). Merriam and Tisdell identify six commonly used approaches or research designs in qualitative research, namely basic qualitative research (also referred to as a generic design), phenomenology, grounded theory, ethnography, narrative analysis and qualitative case study.

This study can be described as a qualitative case study as it involves the description and analysis of a bounded system (Merriam \& Tisdell 2016). The bounded system that defines this case study are all first-year student teachers enrolled in the Social Science module. The module is compulsory for all students who specialise to teach in the Intermediate phase of the primary school. The purpose of a qualitative case study is to find out how people interpret their experiences; how they construct their worlds; and the meaning that they attach to their experiences within a bounded system (Merriam \& Tisdell 2016). This study, as a qualitative case study, set out to explore how research participants constructed meaning pertaining to their experiences in the learning of map work during coursework and fieldwork and to re-imagine how they would teach learners in the Intermediate Phase of the primary school.

The research participants were purposefully sampled as the sample included all first-year Social Sciences students in the Intermediate Phase programme $(n=132)$. These students attended both the field trip and the post field trip lectures. Data was collected using open-ended questionnaires which provided an opportunity for research participants to express themselves using their own frame of reference (Smith 2000). Please see Table 1 below for purposes of reference. 


\section{Table 1: Questions posed in the open-ended questionnaire}

What comes to your mind when you think about maps?

How do you feel about drawing your own maps after your learning in the fieldwork and what was done in the course?

What did you learn from this activity?

How will you teach map skills to Intermediate Phase learners?

Informed consent was obtained from all research participants, with participants being notified of the purpose of the research; their role in terms of time; procedures to be used to protect their anonymity and confidentiality; and that their participation was voluntary.

Using In Vivo coding, words or phrases that the participants used in their responses were selected so as to 'prioritize and honour the participant's voice' (Saldaña 2009:74). Data analysis was inductive as the study set out to combine information from open-ended questionnaires, which were then ordered into larger themes, 'as the researcher work[ed] from the particular to the general' (Merriam \& Tisdell 2016). Thus data was analysed using qualitative content analysis. As such, I discovered patterns and themes that emerged from the data (Patton 2002).

To ensure that the data collected was valid and reliable, I have provided descriptions in the form of quotes to contextualise the phenomenon under study. Examining the consistency of different data sources derived from the same method, namely open-ended questionnaires, referred to by Patton (1999) as triangulation of sources, was also used to determine the validity and reliability of the data collected and analysed.

\section{Findings}

The following themes emerged that highlight the potential of fieldwork in strengthening pedagogic content knowledge necessary to teach map work skills.

\section{Changing the Negative Script that Map work is Complicated}

Almost half of the first-year group had studied Geography up to Grade 12, while the rest of the students last studied Geography in Grade 9. As expected, 
students who chose Geography in high school as one of their specialist subjects expressed a passion for the subject, while the group who studied the subject only up to Grade 9 expressed very little interest in the subject. Thus in one class, there were two groups of students who, from their prior learning experiences, had different levels of knowledge of, and attitudes towards, the subject Geography.

Irrespective of whether they studied Geography in the FET phase or not, the majority of student teachers $(86 \%)$ voiced their dislike of map work. The factors that contributed towards these students disliking map work was that they found it very complicated and challenging. There tended to be a strong correlation between students dislike of map work and their negative experiences at school. Examples from the data show how their recollections of map work triggered 'negative thoughts and attitudes' with memories of how they 'despise[d] map work in high school and as a result would fail'.

These negative attitudes towards map work, and the resultant view that map work is challenging, posed a barrier to their learning of map work in the module. It was clear that the teaching and learning of map work in this module needed a different approach to that which they experienced as learners at school if negative preconceptions were to be changed.

Integrating map work in coursework with learning at the camp seems to have achieved some measure of success in changing students' preconceived views that map work is complicated and challenging. There were numerous instances in the data that support this view, best demonstrated by the following examples. 'It was the best way to learn about maps'; 'It changed my way of thinking about maps'; 'I now see maps less complicated than the way I saw and thought of them before' and 'after this experience, my views about maps have changed as I understand the amount of observation and personal experience that goes into it'.

The process of change was a gradual one for most students, irrespective of when they studied Geography at school. Purposefully scaffolding the learning tasks at the camp and in coursework seems to have helped students change the perspective that map work was complicated. For instance, the following student (Q34) described the change in the following way: 'Having to put all what I saw on paper was the best. Geography to me was all about maps which was complicated to study, until I drew my own map'. Q76 shared a similar view, 'I never thought I can draw maps, and let alone remembering what belonged to the south, east, west and north. I started 
enjoying studying maps when I had to draw my own map'. Thus, participant responses suggest that they experienced their learning at the camp as a valuable resource that formed the foundation for their learning in coursework.

However, a few students (4\%) had reported that they still felt a bit anxious and overwhelmed and continue to harbour negative attitudes towards the learning of maps skills. One of the reasons put forth was the difficulty they encountered with orientating the drawing using the co-ordinates. For example, Q 4 stated that what he/she visualised 'in the head is not easy to put down on paper'. However, one student reported that she/he would not allow their negativity to influence how they would teach map skills to learners as they would draw on the pedagogies that they engaged with in the module when teaching. These students negative ideas about map work etched from their learning at schools was so deeply rooted that it did not successfully change the view that map work is complicated. More will need to be done to improve the teaching of map work at schools combined with increased support at university to change such perceptions. Nevertheless, the different pedagogies used at both the camp and in coursework gave students a different perspective on how they could teach this concept to learners in the primary school.

\section{From Concrete Experience to Active Experimentation}

Student reports about their learning from the concrete experiences provided at the camp led to them experiencing the creation of knowledge when they transferred their observations to drawing their own map. They described their concrete learning experiences of both human-made and natural features on the campsite as allowing them to feel connected to nature. For example, Q 23 stated that he/she had 'never had an experience of exploring the environment' before and now 'felt closer to nature'. One of the reasons for feeling connected to nature as provided by Q 23 was that they had an opportunity to explore the environment and make sense of what surrounds them. It is evident that the first stage of learning from Kolb's four-stage model, namely, that immediate concrete experience $(\mathrm{CE})$ forms the basis of observation and reflection (Kolb 1984) had begun.

The learning in the next stages of Kolb's model, namely, reflective observation abilities (RO), abstract conceptualisation abilities (AC), and active experimentation (AE) were evident when students began translating their first- 
hand experiences from the camp onto a map. Students reported that the initial experiences were unsettling to them, as is evidenced by the following comments: 'It was quite a challenging experience'; 'a bit nerve wrecking'; and 'I was feeling lost'. These initial tensions seemed to have spurred their creativity as they began to assimilate their learning into abstract concepts. As students progressed with the map-drawing task, they reported that they were not only enjoying the task but that it stimulated their interest and motivated them to want to learn more. The experience of drawing one's own map of Achterberg seems to have changed their mindsets about maps. For example, Q 33 stated, 'the camp changed my way of thinking about maps. At first I thought they are very boring but as I drew my own in the assignment, I realized it is very interesting'. A similar view was expressed by Q2, 'I thought that maps are just boring and confusing drawings but after doing this assignment I kind of fell in love with it because....I got to put my experience on paper'. Students also demonstrated that in order for them to learn from the map-drawing activity, also referred to as the transformation stage for constructing new knowledge, they first needed to grasp the information learnt in coursework. There were numerous such examples from the data, best captured by the following excerpts: 'maps are fun and easy as long as you understand what you are doing'; 'having a clear understanding of the content makes maps less complex'; and 'if you do not understand how to read maps you will never be able to interpret it'. These comments from students are indicative of them recognizing the importance of having a good understanding of the content knowledge pertaining to map work skills if they are to apply these skills successfully in the map drawing activity.

In addition, concrete experiences acquired from the camp did form the basis for observations and reflections as evidenced by the following statements from students, that: 'exploring the environment' prior to drawing the map 'teaches me to reflect on one's drawings' and 'after drawing that map, I felt good as I have not done anything like that in my past'. Other statements that support this view are: 'It broke my limitations of what I could apply' and prompted 'the need to learn more about maps because they are so interesting'. Q12 explained it succinctly as feeling 'like a true cartographer by coming up with my own keys and using my own hands to create something so beautiful'. The above data clearly demonstrates Kolb's four-stage model of learning where knowledge is created through the transformation of experience. At the core of Kolb's four-stage model, immediate concrete experience forms the 
basis of observation and reflection (Kolb 1984). The data does show that concrete experiences at the camp enabled reflection, abstract conceptualisation and active experimentation with the map drawing activity.

\section{Learning In and From the Environment Breathes 'Life' into Maps}

Students' understanding of important concepts in map work was strengthened when their learning was linked to the environment. One of the reasons provided was that learning in and from the environment brought maps to 'life' making learning real and relevant. Once again, there were numerous instances of this in the data, evidenced in the following accounts,

'the world of reality fitted onto a small page';

'a source of information that is not made up of fictional things, they are replicas of real places';

'sometimes you need to do things practical than more theory'; and 'map work is very understandable when you have actually been to the place you are drawing a map about. The memory made it easy to draw'.

Learning in and from the environment strengthened students content knowledge pertaining to important map work concepts such as direction, distance, co-ordinates, symbols, scale. Moreover, students were also learning how to apply these concepts when drawing their own maps, resulting in one student drawing the conclusion that 'maps and map drawing are distinct skills in Geography'. The activity enabled an understanding and realisation that maps are important resources that can be useful in daily life. The following comments supports this notion: 'that maps are actually the resources that you can use to get to know a place'; 'interpret weather and climate'; 'learn about landmarks' and 'is a good way to teach people about our environment, what happens around us'.

Using the environment as a learning resource seems to have strengthened specific skills, such as the skills of observation, drawing, listening and communication. Students recognised that the activity taught them the importance of paying careful attention to detail at the camp and in drawing the map. This is evident in the following quotes from students: 'a person has to be 
very observant of their surroundings'; 'even small things do matter'; and 'that there are some things we take for granted because we see them every day'. The activity has also developed their skills of drawing, as described by Q 36: "this assignment has improved my drawing skills and being able to take reality and place it in a drawing'. Another student (Q10) also reported that she/he 'learnt (about) my weaknesses and my strength'. Students were also learning the skills of communication when working in groups. For example, the following excerpt from Q 48 points to the kind of learning that is taking place: 'to respect others and also listen to them and learnt how to interact. Patience is a virtue'. The data thus confirms that the environment was a valuable resource that not only strengthened students' content knowledge but also developed specific skills in map work. The value of experiential learning in providing learners opportunities to develop knowledge and skills (Dillon, Rickinson, Teamey, Morris, Choi, Sanders \& Benefield 2006), in this case, pertaining to learning map skills, is evident in the data.

\section{Transitioning from Student to Thinking Like a Teacher}

The data confirms that students were able to draw on their own learning experiences to reflect on how they would teach map work to learners in the Intermediate Phase of the primary school. In so doing, the next cycle in Kolb's experiential theory commenced by using their concrete experiences (CE) to reflect $(\mathrm{RO})$ and conceptualise $(\mathrm{AC})$.

The eco-exploration activity at the camp integrated well with coursework to enable students to better understand map work skills, and simultaneously introduced them to strategies on how to teach this section to learners in the primary school. Students expressed the aim to model their teaching on how they were taught in the module. For example, they described how they would take learners outside the classroom to explore their immediate environment, similar to their eco-exploration experiences at the camp, to gain a hands-on learning experience. Students were also able to consider different ways to simulate their learning experiences in the school environment. They recognised that the outdoors was the best learning environment and this is evident in the following comments: 'practical experiences are always the best'; 'I will teach through adventurous activities even outside the classroom'. In addition, students provided examples of learning activities that they will 


\section{Sarita Ramsaroop}

undertake when teaching learners. The examples they provide is suggestive of them already thinking ahead of what possible difficulties and misconceptions learners may have when teaching map skills. Descriptions from the data that point to this are, 'pointing out the east, west, north and south to make things easier for them'; 'letting them draw a map of the school using a scale' and 'teaching them to pay attention to each feature ... to put it in a paper when drawing a map'. The use of visual resources such as drawings and pictures were also provided as examples that could be used to simplify maps to learners. These examples also suggest that students intend to include different learning styles into their teaching. In Kolb's model, different learning styles are incorporated, giving credence to the notion that individuals have preferred learning styles (Kolb 1984).

Students demonstrated the ability to reflect by drawing on specific details that they said contributed to the success of their own learning when reimagining how they will teach learners. Examples from the data that indicate such reflection are, 'I will do like they did to me at Achterbergh with placing the instructions so that every learner that followed those instructions can do well'; 'I will allow them to share their ideas'; 'I will first help them understand the basics of maps. Give them easier activities and as time goes on the difficulty of the activities will increase to increase their knowledge as well' and 'I will also want them to have fun when doing it'. It would seem that students are reflecting on their own concrete experiences to assimilate a similar experience for their own learners. In so doing, students are demonstrating not only 'how' they would teach, but they are also beginning to conceptualise 'why' they would make specific teaching and learning choices.

\section{Discussion of Findings}

The data supports the view that student teachers learning of map work was strengthened when the module was purposefully designed in accordance with the learning cycle of Kolb's experiential theory to integrate coursework with fieldwork. Specific to student teachers learning about map work, the data confirms that the integration of coursework with fieldwork resulted in the majority of student teachers changing their preconceived views that map work is complicated. From the data, these students did not initially share the same enthusiasm for learning map work. It was clear that student teachers' prior 
experiences of learning Geography caused some students to harbour negative attitudes towards the subject. Unfortunately, a few of these students were still not able to move beyond their preconceived notions that map work is difficult, acquired from their school experiences. These negative attitudes will impact negatively on their learning of new concepts and also on how they will teach (Darling-Hammond 2006; Feiman-Nemser 2008). These findings brings to light the need for a more robust professional discourse about how map work is currently taught in South African schools, and the need to begin developing Geography teachers to change the 'how' of their practice.

These forms of prior knowledge and preconceptions about teaching can positively or negatively shape the way that student teachers think (DarlingHammond 2006; Feiman-Nemser 2008) about the teaching and learning of map work. Feimna-Nemser (2008) asserts that changing preconceived ideas about teaching and learning requires student teachers to critically examine their existing beliefs, against a backdrop of new ideas and understandings. I would argue that integrating fieldwork and coursework in the module design provided the backdrop for such new ideas and understandings. The data confirms that their initial views of map work were altered for the majority of student teachers.

The data also confirms that student teachers' content knowledge of map work had improved when the learning cycle of Kolb's experiential theory was used to integrate coursework and fieldwork. I would argue that such integration contributed towards strengthening the pedagogic content knowledge (PCK) of student teachers. Shulman (1987:8) describes PCK as 'that special amalgam of content and pedagogy that is uniquely the province of teachers, their own special form of professional understanding'. It represents the ability of a teacher to effectively blend content and pedagogy relevant to a specific domain so as to tailor the curriculum and content to meet the needs of learners with diverse abilities (Shulman 1987). Student teachers' learning was strengthened with regards to 'knowledge of the content, of the process for learning this content, and the nature of student thinking, reasoning, understanding, and performance within a subject area' (Darling-Hammond \& Baratz-Snowden 2005:17) when fieldwork was integrated into coursework. The data does confirm that student teachers were reasoning and understanding when they indicated that, for them to learn from the map drawing activity, also referred to as the transformation stage for constructing new knowledge (Kolb 1984), they need to first grasp the information learnt in the coursework. As 


\section{Sarita Ramsaroop}

such, student teachers were clearly reflecting on their own learning. Such reflection represents the early stages of student teachers' development of professional knowledge as they make 'the tacit explicit, meaningful, and useful' (Loughran 2002:38).

From the data, student teachers acknowledged that while the different pedagogies used in the module enabled them to understand map work better; these pedagogies also prompted them to re-imagine how they would teach map skills to learners in the primary school. It was clear that student teachers aimed to model the teaching practices that they experienced in the module. If student teachers are to question their own assumptions and beliefs about teaching, they need to experience their own learning in much the same way as they will ultimately teach it (Darling-Hammond 2006). This, I argue, is crucial to changing student teachers' preconceived notions of teaching and learning in Geography, especially in map work.

The phenomenon of teacher agency surfaced as a crucial variable in enabling student teachers' learning to teach map work skills. In explaining agency, I draw upon the views of Biesta and Tedder (2007:137) who explain that the concept of agency places emphasis on individuals always acting ...

by means of their environment rather than simply in their environment ... the achievement of agency will always result from the interplay of individual efforts, available resources and contextual and structural factors as they come together in particular and, in a sense, always unique situations.

The findings of this study points to how student teachers' agency can be developed through learning in concrete settings and through particular ecological conditions and circumstances (Biesta \& Tedder 2006), thus enabling student teachers to develop confidence in 'what' and 'how' they teach. I would argue that using the learning cycle of Kolb's experiential theory to integrate coursework with fieldwork enabled student teachers to take 'agentic' action by reflecting and making choices on how they could teach learners map work skills in the primary schools in South Africa. Student teachers were exhibiting the projective dimension of agency, which Biesta and Tedder (2006) describe as not merely repeating past actions but reimagining new possibilities for thought and action. 
From the data, examples as articulated by students, such as: 'I will teach through adventurous activities'; 'I would let them draw a map of the school using a scale'; 'I will teach them to pay attention to each feature'; 'help them to learn better through seeing and drawings', demonstrate that student teachers were developing a vision of how they would teach map skills to the Intermediate Phase learners.

As expressed by Biesta, Priestley and Robinson (2015:637), these beliefs do make a difference pertaining to the extent and degree to which teachers, in this case student teachers, are able to 'achieve agency within the particular educational ecologies in which they work' An ecological understanding of agency suggests that it is something that can be achieved in and through engagement, and strongly connected to context (Biesta et al. 2015). The locus of agency is about constructing narratives to locate future possibilities over time (Biesta \& Tedder 2006).

What has enabled student teachers to develop agency? To answer the question that I pose, I turn to Emirbayer and Mische (1998 cited by Biesta et al. 2015:626) who suggest that agency should be understood as a 'configuration of influences from the past, orientations towards the future and engagement with the present'. Drawing on the findings, I would assert that using Kolb's experiential learning theory in integrating student teachers' learning in coursework and fieldwork not only makes learning real and relevant, but it enables student teachers to exhibit agency.

The findings confirm that the majority of student teachers reconfigured their understandings and misconceptions of map work from their past experiences, engaged with the present (learning in coursework and fieldwork) to re-orientate their learning towards their future practices (how they would teach learners).

\section{Conclusion}

This research set out to explore how first-year student teachers merged their learning of map work in a coursework module with a fieldwork component to re-imagine how they would teach learners map skills in the Intermediate Phase of the primary school. The findings support the view that student teachers' learning of map work was strengthened when the module was purposefully designed in accordance to the learning cycle of Kolb's experiential theory to 
integrate coursework with fieldwork. In addition, the phenomenon of teacher agency surfaced as a crucial variable in enabling student teachers' learning to teach map work. Student teachers' agency was developed through learning in concrete settings and through particular ecological conditions and circumstances. I argue that by student teachers acquiring a 'hands-on' experiential learning experience that integrates with coursework, student teachers were empowered to take agentic action by reflecting and making informed pedagogical choices on how they would teach this content area to learners in the primary school. As such, the foundations for learning to teach geographical enquiry skills were developed.

\section{References}

Beets, P. \& L. le Grange 2005. Continuity and Progression: The Achilles Heel of the National Curriculum Statement for Geography? South African Journal of Education 25,3: 190 - 197. Available at: https://www.ajol.info/index.php/saje. (Accessed on 28 May 2017.)

Biesta, G., M. Priestley \& S. Robinson 2015. The Role of Beliefs in Teacher Agency. Teachers and Teaching 21,6: 624 - 640. Available at:

https://www.tandfonline.com/doi/abs/10.1080/13540602.2015.1044326. (Accessed on 17 August 2016.)

https://doi.org/10.1080/13540602.2015.1044325

Biesta, G. \& M. Tedder 2007. Agency and Learning in the Lifecourse: Towards an Ecological Perspective. Studies in the Education of Adults 39,2: 132 149. Available at: https://www.tandfonline.com/loi/rsia. (Accessed on 17 August 2016.)

https://doi.org/10.1080/02660830.2007.11661545

Biesta, G. \& M. Tedder 2006. How is Agency Possible? Towards an Ecological Understanding of Agency-as-achievement. Learning Lives: Learning, Identity, and Agency in the Life Course. Available at: http://www.learninglives.org/papers/working papers/Working paper 5 _Exeter_Feb_06.pdf (Accessed on 17 August 2016.)

Brunn, S.D. \& M. Dodge 2017. What is Where? The Role of Map Representations and Mapping Practices in Advancing Scholarship. In Mapping Across Academia. Dordrecht: Springer. https://doi.org/10.1007/978-94-024-1011-2 1 https://doi.org/10.1007/978-94-024-1011-2 
Darling-Hammond, L. 2006. Powerful Teacher Education: Lessons from Exemplary Programs. Hoboken, NJ: John Wiley \& Sons.

Darling-Hammond, L. 2006. Powerful Teacher Education: Lessons from Exemplary Programs. Hoboken, NJ: John Wiley \& Sons.

Darling-Hammond, L. \& J. Baratz-Snowden 2005. A Good Teacher in every Classroom. Preparing the Highly Qualified Teachers our Children Deserve. San Francisco, CA: Jossey-Bass.

Day, T. 2012. Undergraduate Teaching and Learning in Physical Geography. Progress in Physical Geography 36,3: 305 - 332. Available at: https://doi.org/10.1177/0309133312442521 (Accessed on 16 June 2017.)

Department of Basic Education 2011. National Curriculum Statement. Curriculum and Assessment Policy Statement (CAPS). Social Science Intermediate Phase Grades 4 - 7. Pretoria, South Africa.

Department of Education. 2007. National Education Policy Framework for

Teacher Education and Development in South Africa. Government

Gazette (Vol 29832, No. 502.) Pretoria: Government Printer.

Department of Higher Education and Training. 2015. Revised Policy on the Minimum Requirements for Teacher Education Qualifications. National Qualifications Framework Act 67 (2008). Government Gazette (Vol. 38487 No. 596.) Pretoria: Government Printer.

Dillon, J., M. Rickinson, K. Teamey, M. Morris, M.Y. Choi, D. Sanders \& P. Benefield 2006. The Value of Outdoor Learning: Evidence from Research in the UK and Elsewhere. School Science Review 87,320: 107. Available at: https://www.ase.org.uk/journals/school-science-review/. (Accessed on 12 February 2016).

Feiman-Nemser, S. 2008. Teacher Learning. How do Teachers Learn to Teach? In Cochran-Smith, M., S. Feiman-Nemser \& D.J. McIntyre (eds): Handbook of Research on Teacher Education. Enduring Questions in Changing Contexts. $3^{\text {rd }}$ Edition. New York: Routledge.

Fuller, I.C. 2006. What is the Value of Fieldwork? Answers from New Zealand using Two Contrasting Undergraduate Physical Geography Field Trips. New Zealand Geographer 6,23: 215 - 220. Available at: https://www.ncbi.nlm.nih.gov/labs/journals/n-Z-geog/. (Accessed on 12 February 2016.)

https://doi.org/10.1111/j.1745-7939.2006.00072.x

Greene, J.P., B. Kisida \& D.H. Bowen 2014. The Educational Value of Field 
Trips. Education Next 14,1: 78 - 86. Available at: https://www.educationnext.org/ (Accessed on 12 February 2016).

Innes, L.M. 2012. South African School Geography: Underpinning the Foundation of Geospatial Competence. South African Journal of Geomatics 1,1: 92 - 108. Available at:

https://www.ajol.info/index.php/sajg. (Accessed on 18 August 2016). Innes, L.M. 2003. Maths for Map Users. In $21^{\text {st }}$ ICA (International Cartographic Association) Conference, Durban, South Africa. Available at: https://icaci.org/icc2003/. (Accessed on 18 August 2016.)

Innes, L.M. 2002. Evaluating Learning Materials for Map Reading. In Regional Conference of the IGU (International Geographical Union), Durban, South Africa. Available at: https://igu-online.org/wpcontent/uploads/2014/03/jan_20071.pdf. (Accessed on 18 August 2016).

Koc, H. \& S.B. Demir 2014. Developing Valid and Reliable Map Literacy Scale. Review of International Geographical Education Online (RIGEO) 4,2: 120. Available at: https://www.journalguide.com/reviewof-international-geographical-education-online. (Accessed on 15 March 2018).

Kolb, D.A. 1984. Experiential Learning: Experience as the Source of Learning and Development. Englewood Cliffs, NJ: Prentice Hall.

Korthagen, F.A.J., J. Loughran \& T. Russell 2006. Developing Fundamental Principles for Teacher Education Programs and Practices. Teaching and Teacher Education 22:1020 - 1041. Available at:

https://www.journals.elsevier.com/teaching-and-teacher-education/.

(Accessed on 01 June 2012.)

https://doi.org/10.1016/j.tate.2006.04.022

Larangeira, R. \& C.D. Van der Merwe 2016. Map Literacy and Spatial Cognition Challenges for Student Geography Teachers in South Africa. Perspectives in Education 34,2: 120 - 138. Available at: https://journals.co.za/content/journal/persed. (Accessed on $15 \mathrm{March}$ 2018.)

https://doi.org/10.18820/2519593X/pie.v34i2.9

Liben, L.S., K.A. Kastens \& L.M. Stevenson 2002. Real-world Knowledge through Real-world Maps: A Developmental Guide for Navigating the Educational Terrain. Developmental Review 22,2: 267 - 322. Available at: https://www.journals.elsevier.com/developmental-review. (Accessed on 09 April 2017.) 
https://doi.org/10.1006/drev.2002.0545

Lloyd, R.T. \& R.L. Bunch 2010. Learning Geographic Information from a Map and Text: Learning Environment and Individual Differences. Cartographica 45,3: 169-184. Available at:

http://dx.doi.org/10.3138/carto.45.3.169. (Accessed on 18 August 2016.) https://doi.org/10.3138/carto.45.3.169

Loughran, J.J. 2002. Effective Reflective Practice: In Search of Meaning. Learning about Teaching: Journal of Teacher Education 53,1: 33 - 43. Available at: https://www.journals.elsevier.com/teaching-and-teachereducation/. (Accessed on 01 June 2017.)

https://doi.org/10.1177/0022487102053001004

Maxim, G.W. 1997. Developmentally Appropriate Map Skills Instruction. Childhood Education 73,4: 206 - 211. Available at:

https://www.tandfonline.com/loi/uced20. (Accessed on 17 August 2016.) https://doi.org/10.1080/00094056.1997.10521094

Merriam, S.B. \& E.J. Tisdell 2016. Qualitative Research. A Guide to Design and Implementation. $4^{\text {th }}$ Edition. [ebook]. San Francisco, CA: JosseyBass.

Natoli, S.J. 1988. Strengthening Geography in Social Studies. NCSS Bulletin 82. Washington, DC: National Council for the Social Studies.

Ndlwana, M. 1991. A Critical Analysis of Problems Encountered by Senior Secondary School Pupils in the Reading and Interpretation of 1:50 000 Topographical Maps and Aerial Photographs with Special Reference to Black Pupils in Transkei. Grahamstown (South Africa): Unpublished M.Ed. Thesis, Rhodes University.

Noel, A.M. \& M.A. Colopy 2006. Making History Field Trips Meaningful: Teachers' and Site Educators' Perspectives on Teaching Materials. Theory \& Research in Social Education 34,4: 553 - 568. Available at:

www.tandfonline.com/doi/abs/10.1080/00933104.2006.10473321.

(Accessed on 12 February 2016.)

https://doi.org/10.1080/00933104.2006.10473321

Patton, M.Q. 2002. Qualitative Research \& Evaluative Methods. $3^{\text {rd }}$ Edition. Thousand Oaks, CA: Sage.

Patton, M.Q. 1999. Enhancing the Quality and Credibility of Qualitative Analysis. Health Services Rresearch 34,5 Pt 2: 1189 - 1208. Available at: www.hsr.org/. (Accessed on 01 February 2000.) 
Reitano, P. \& W. Harte 2016. Geography Pre-service Teachers' Pedagogical Content Knowledge. Pedagogies: An International Journal 11,4: 279 291. Available at: https://www.tandfonline.com/loi/hped20. (Accessed on 16 August 2016.)

Saldaña, J. 2009. The Coding Manual for Qualitative Researchers. Thousand Oaks, CA: Sage.

Shulman, L.S. 1987. Knowledge and Teaching: Foundations of the New Reform. Harvard Educational Review 57,1: 1 - 21. Available at:

https://dbh.nsd.uib.no/publiseringskanaler/erihplus/periodical/info.action ?id=441051. (Accessed on 12 March 2011.)

https://doi.org/10.17763/haer.57.1.j463w79r56455411

Smith, C.P. 2000. Content Analysis and Narrative Analysis. In Reis, T. \& C. Judd (eds.): Handbook of Research Methods in Social and Personality Psychology. Cambridge: Cambridge University Press.

Umalusi and Higher Education South Africa 2010. Evaluating the South African National Senior Certificate in Relation to Selected International Qualifications: A Self-referencing Exercise to Determine the Standing of the NSC. Pretoria, South Africa.

Weeden, P. 1997. Learning through Maps. Teaching and Learning Geography. London: Routledge.

Ying, N.K. 1997. Students' Perceptions of Mapwork: A Case Study. Unpublished. Master's thesis, University of Hong Kong.

Yoshida, K. 2015. Problems and Perspectives of Geography Education in Japanese Elementary Schools. In Ida, Y. et al. (eds.): Geography Education in Japan. Tokyo: Springer.

https://doi.org/10.1007/978-4-431-54953-6_2

Sarita Ramsaroop Department of Childhood Education Faculty of Education University of Johannesburg saritaram@uj.ac.za 